\begin{tabular}{|c|c|c|}
\hline UNNFS & $\begin{array}{l}\text { Jurnal Fisika } 10 \text { (2) (2020) 50-61 } \\
\text { Jurnal Fisika } \\
\text { https://journal.unnes.ac.id/nju/index.php/jf/index }\end{array}$ & $\begin{array}{l}\text { Jurnal Fisika } \\
\equiv\end{array}$ \\
\hline & & \\
\hline
\end{tabular}

\title{
Kajian Kondisi Atmosfer dan Rekonstruksi Hujan pada Kejadian Banjir di Lamandau menggunakan Radar Cuaca Doppler C-Band
}

\section{Deffi Munadiyat Putri ${ }^{1 \bowtie}$ dan Nelly Handayani ${ }^{2}$}

${ }^{1}$ Stasiun Meteorologi Iskandar Kotawaringin Barat, Jl. Iskandar, Bandar Udara Iskandar Kotawaringin Barat, Kalimantan Tengah, 741112, Indonesia

${ }^{2}$ Stasiun Meteorologi Beringin Barito Utara J1. Pendreh, No. 187, Muara Teweh, Barito Utara, Kalimantan Tengah, 73811, Indonesia

\begin{tabular}{|c|c|}
\hline Info Artikel & ABSTRAK \\
\hline Sejarah Artikel: & Gangguan cuaca yang menyebabkan terjadinya hujan dapat berpotensi menimbulkan bencana \\
\hline $\begin{array}{l}\text { Diterima: } \\
3 \text { Oktober } 2020\end{array}$ & $\begin{array}{l}\text { hidrometeorologi yang mengakibatkan kerugian. Penelitian ini bertujuan untuk mengkaji kondisi } \\
\text { atmosfer dan awan penyebab hujan yang menyebabkan terjadinya banjir di Lamandau. Kajian }\end{array}$ \\
\hline Disetujui: & dinamika atmosfer dilakukan dengan mempertimbangkan anomali suhu permukaan laut, pola \\
\hline 23 Desember 2020 & MSLP, streamline, dan moisture transport. Kajian terhadap awan hujan memanfaatkan radar cuaca \\
\hline $\begin{array}{l}\text { Dipublikasikan: } \\
28 \text { Desember } 2020\end{array}$ & $\begin{array}{l}\text { Doppler melalui produk CMAX dan MLVCUT, sedangkan rekonstruksi estimasi curah hujan } \\
\text { temporal menggunakan produk RIH. Gangguan cuaca yang memicu terjadinya cuaca buruk di } \\
\text { wilayah Lamandau adalah terjadinya peningkatan suhu permukaan laut yang didukung oleh }\end{array}$ \\
\hline $\begin{array}{l}\text { Keywords: } \\
\text { weather disturbances, } \\
\text { Doppler weather } \\
\text { radar, sea surface } \\
\text { temperature, rainfall }\end{array}$ & $\begin{array}{l}\text { konsentrasi uap air yang cenderung lebih tinggi dibandingkan wilayah lainnya. Awan penyebab } \\
\text { hujan tumbuh mulai pukul } 09.00 \text { hingga } 10.30 \text { UTC dengan reflectivity maksimum mencapai } 55 \text { - } \\
60 \mathrm{dBz} \text { yang terklasifikasi sebagai awan konvektif. Rekonstruksi QPE di wilayah penelitian } \\
\text { menunjukan bahwa hujan terjadi dalam durasi } 40 \text { menit dengan intensitas puncak sebesar } 55.2 \\
\mathrm{~mm} / \text { jam pukul } 10.00 \text { UTC. }\end{array}$ \\
\hline
\end{tabular}

\section{ABSTRACT}

Weather disturbances that cause rainfall can potentially lead to hydrometeorological disasters resulting in losses. This study aims to examine the conditions of the atmosphere and clouds that cause rain which causes flooding in Lamandau. The study of atmospheric dynamics is carried out by considering sea surface temperature anomalies, MSLP patterns, streamline, and moisture transport. The study of rain clouds utilizes Doppler weather radar through the CMAX and MLVCUT products, while the reconstruction of temporal rainfall estimation using RIH product. Weather disturbances that triggers bad weather in Lamandau region is the result of an increase in sea surface temperature which is supported by differences in MSLP and the presence of shearline around the area with water vapor concentrations that tend to be higher than other areas. Clouds that cause rain grow from 09.00 to 10.30 UTC with maximum reflectivity reach 55 - $60 \mathrm{dBz}$ which is classified as a convective cloud. The QPE reconstruction in the study area shows that rain occurs for a duration of 40 minutes with the peak of intensity reach $55.2 \mathrm{~mm} /$ hour at 10.00 UTC

(C) 2020 Universitas Negeri Semarang

\footnotetext{
Alamat korespondensi:

Stasiun Meteorologi Iskandar Kotawaringin Barat

E-mail: deffi.munadiyat.putri@gmail.com
} 


\section{PENDAHULUAN}

Bencana hidrometeorologi dapat menyebabkan berbagai kerugian harta benda, korban jiwa dan kerusakan lingkungan (Kristianto \& Putri, 2020). Awan cumuliform dapat menyebabkan hujan yang menimbulkan bencana banjir (Nababan \& Tjasyono, 2016). Intensitas hujan tinggi menjadi hal yang krusial, untuk itu selain dibutuhkan stasiun cuaca dibeberapa tempat yang mewakili, juga diperlukan data satelit maupun radar cuaca untuk dapat diketahui intensitas hujan secara spasial dan temporal yang berpotensi menyebabkan banjir (Adi, 2017).

Radar cuaca memiliki kemampuan yang baik dalam mendeteksi kondisi hydrometeor (Gunawan dkk., 2014). Kajian menggunakan radar cuaca menunjukan bahwa instrumen ini mampu mengidentifikasi nilai reflectivity pada tahap perkembangan yang dimiliki oleh awan penyebab hujan (Habib dkk., 2019 dan Prasetyo dkk., 2019). Estimasi presipitasi secara kuantitatif (QPE) dihitung melalui hubungan reflectivity-rain rate radar (Z-R) (Paski \& Permana, 2018). Radar cuaca digunakan untuk menutupi kekurangan pengukuran karena ketebatasan jumlah alat pengukur curah hujan. Produk pada radar cuaca menghasilkan data reflectivity ( $Z$ ), sehingga untuk mendapatkan data estimasi curah hujan diperlukan pengolahan dengan hubungan reflectivity $(\mathrm{Z})$ dan rain rate $(\mathrm{R})$ atau hubungan Z-R yang dapat berbeda pada setiap kondisi. Penelitian mengenai estimasi curah hujan dengan radar cuaca di Pangkalan Bun menyatakan bahwa CMAX merupakan produk yang paling representatif dalam estimasi curah hujan sedangkan untuk penggunaan hubungan Z-R produk SRI Rosenfeld Tropical memiliki hasil yang terbaik (Dewi, 2018).

Penelitian ini bertujuan untuk melakukan kajian terhadap kondisi atmosfer dan awan penyebab hujan yang mengakibatkan banjir di wilayah Lamandau pada 20 Juni 2020. Kajian terhadap kondisi atmosfer ini perlu dilakukan agar dapat diketahuilebih lanjut gangguan cuaca yang berperan dalam menyebabkan banjir serta intensitas curah hujan pada saat kejadian berdasarkan hasil rekonstruksi hujan dari produk hidrologi radar cuaca dan karakteristik awan penyebab hujan sehingga dapat digunakan sebagai bahan prakiraan selanjutnya agar dampak yang diakibatkan oleh banjir dapat diminimalisasi.Gangguan cuaca merupakan kondisi dinamika udara yang secara cepat akan mengubah kondisi cuaca yang berbeda dari sebelumnya, misalnya dari kondisi cerah berubah ke kondisi berawan dan hujan atau sebaliknya (Azka dkk., 2018).

\section{METODE}

Lokasi yang menjadi domain pada penelitian ini adalah Kabupaten Lamandau, Kalimantan Tengah pada 20 Juni 2020. Lokasi penelitian ditunjukkan pada peta Gambar 1. Wilayah penelitian ini berjarak $60 \mathrm{~km}$ dari lokasi radar cuaca Stasiun Meteorologi Iskandar.

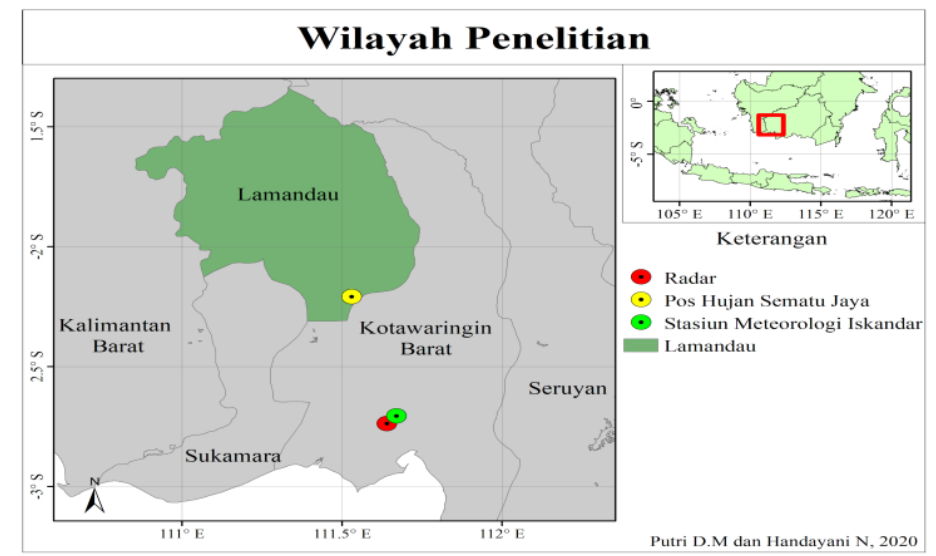

Gambar 1. Peta wilayah penelitian 
Data yang digunakan dalam penelitian ini antara lain: (i) Anomali suhu permukaan laut 17 20 Juni 2020 dari Physical Sciences Laboratory NOAA, (ii) Peta spasial Mean Sea Level Pressure (MSLP) pukul 00.00 UTC dan streamline angin gradien pukul 00.00 dan 12.00 UTC tanggal 20 Juni 2020 dari Bureau of Meteorology (BOM) Australia, (iii) Angin u dan v serta kelembapan spesifik lapisan 1000 hingga 300 mb ERA5 dari Climate Data Store Copernicus, dan (iv) Raw data ekstensi volumetrik Radar C-Band dari Stasiun Meteorologi Iskandar Kotawaringin Barat.

Proses terbagi ke dalam dua bagian utama yaitu bagian analisis dinamika atmosfer dan analisis awan penyebab hujan yang menimbulkan banjir di kabupaten Lamandau. Proses analisis dinamika atmosfer dilakukan dengan mempertimbangan kondisi yang ditunjukan oleh anomali suhu permukaan laut, pola MSLP, streamline dan moisture transport untuk mengetahui gangguan cuaca penyebab hujan lebat.. Moisture transport dihitung menggunakan Persamaan 1.

$$
Q=\frac{1}{g} \int_{300}^{p_{s}}(V q) d p
$$

Komponen zonal dinyatakan pada Persamaan 2 sedangkan meridional ditunjukkan pada Persamaan 3.

$$
\begin{aligned}
& Q_{\lambda}=\frac{1}{g} \int_{300}^{p_{s}}(u q) d p \\
& Q_{\varphi}=\frac{1}{g} \int_{300}^{p_{s}}(v q) d p
\end{aligned}
$$

di mana $g$ adalah percepatan gravitasi; $V$ vektor angin dua dimensi; $u$ dan $v$ adalah kecepatan angin zonal dan meridional; $q$ kelembaban spesifik dan $p_{s}$ adalah tekanan permukaan (Xiaoxia dkk., 2010)

Bagian kedua merupakan proses analisis awan melalui radar cuaca sehingga proses evolusinya dapat diketahui secara lebih baik melalui produk Column Maximum (CMAX) dan Multiple Line Vertical Cut (MLVCUT). Bagian kedua juga mencakup proses estimasi intensitas curah hujan temporal untuk rekonstruksi hujan menggunakan produk Rainfall Intensity Histogram (RIH) turunan dari CMAX. Analisis spasial dilakukan dengan memanfaatkan produk Surface Rainfall Intensity (SRI). Hubungan Z$\mathrm{R}$ dalam produk SRI dengan menggunakan Persamaan 4.

$$
Z=a R^{b}
$$

dimana $\mathrm{Z}$ merupakan faktor reflectivity $\left(\mathrm{mm}^{6} / \mathrm{m}^{3}\right)$ sedangkan a mewakili diameter ukuran droplet dalam satu sampling volume dan $\mathrm{b}$ mewakili kondisi equilibrium perubahan droplet pada satu sampel volume yang masing-masing nilainya 250 dan 1.2 (Dewi, 2018). Berdasarkan penelitian (Dewi, 2018), hubungan Z-R ini merupakan pengaturan terbaik yang dapat diterapkan di wilayah Pangkalan Bun. Identifikasi terhadap jenis awan juga dilakukan melalui klasifikasi awan berdasarkan gerak vertikal awan konvektif dan stratiform yang dijelaskan pada Tabel 1. (Widomurti, 2017). 
Deffi Munadiyat Putri, dkk. / Jurnal Fisika 10 (2) (2020) 50-61

Tabel 1. Rentang VIP level curah hujan

\begin{tabular}{|c|c|c|c|c|c|c|}
\hline \multirow{3}{*}{ VIP Level } & \multicolumn{3}{|c|}{ Statiform } & \multicolumn{3}{|c|}{ Konvektif } \\
\hline & \multirow{2}{*}{$\begin{array}{c}\text { Reflectivity } \\
\text { (dBz) }\end{array}$} & \multicolumn{2}{|c|}{$\begin{array}{c}\text { Curah Hujan } \\
\text { (mm/jam) }\end{array}$} & \multirow{2}{*}{$\begin{array}{l}\text { Reflectivity } \\
\text { (dBz) }\end{array}$} & \multicolumn{2}{|c|}{$\begin{array}{c}\text { Curah Hujan } \\
\text { (mm/jam) }\end{array}$} \\
\hline & & Radar & Observasi & & Radar & Observasi \\
\hline Ringan & $13-31$ & $0.1-1.38$ & $1.0-5.0$ & - & - & - \\
\hline Sedang & $31-37$ & $1.38-6.92$ & $5.0-10.0$ & - & - & - \\
\hline Lebat & - & - & - & $38-49$ & $6.92-18.49$ & $10.0-20.0$ \\
\hline Sangat Lebat & - & - & - & $>49$ & $>18.49$ & $>20$ \\
\hline
\end{tabular}

\section{HASIL DAN PEMBAHASAN}

\section{Anomali Suhu Muka Laut}

Distribusi spasial anomali suhu permukaan laut ditunjukkan oleh Gambar 2, dimana Laut Jawa menunjukan nilai yang beragam. Perairan selatan Kalimantan yang berhubungan langsung dengan Teluk Kumai memiliki nilai anomali positif yang cenderung lebih besar dibandingkan wilayah lainnya di bagian utara Laut Jawa yaitu sebesar 0.5 hingga $1{ }^{\circ} \mathrm{C}$. Anomali positif ini bertahan mulai dari 17 Juni hingga 19 Juni 2020. Anomali positif di perairan Jawa cenderung berada di sepanjang pesisir pantai dan pada bulan Juni anomali negatif masih terkonsentrasi di perairan selatan Sulawesi sehingga belum meluas pada bagian lain di Laut Jawa (Nuryanto \& Anggraeni, 2018). Keadaan laut yang cenderung hangat akan mengakibatkan penguapan di perairan menjadi lebih giat sehingga dapat membantu pertumbuhan awan konvektif (Mughozali dkk., 2017).

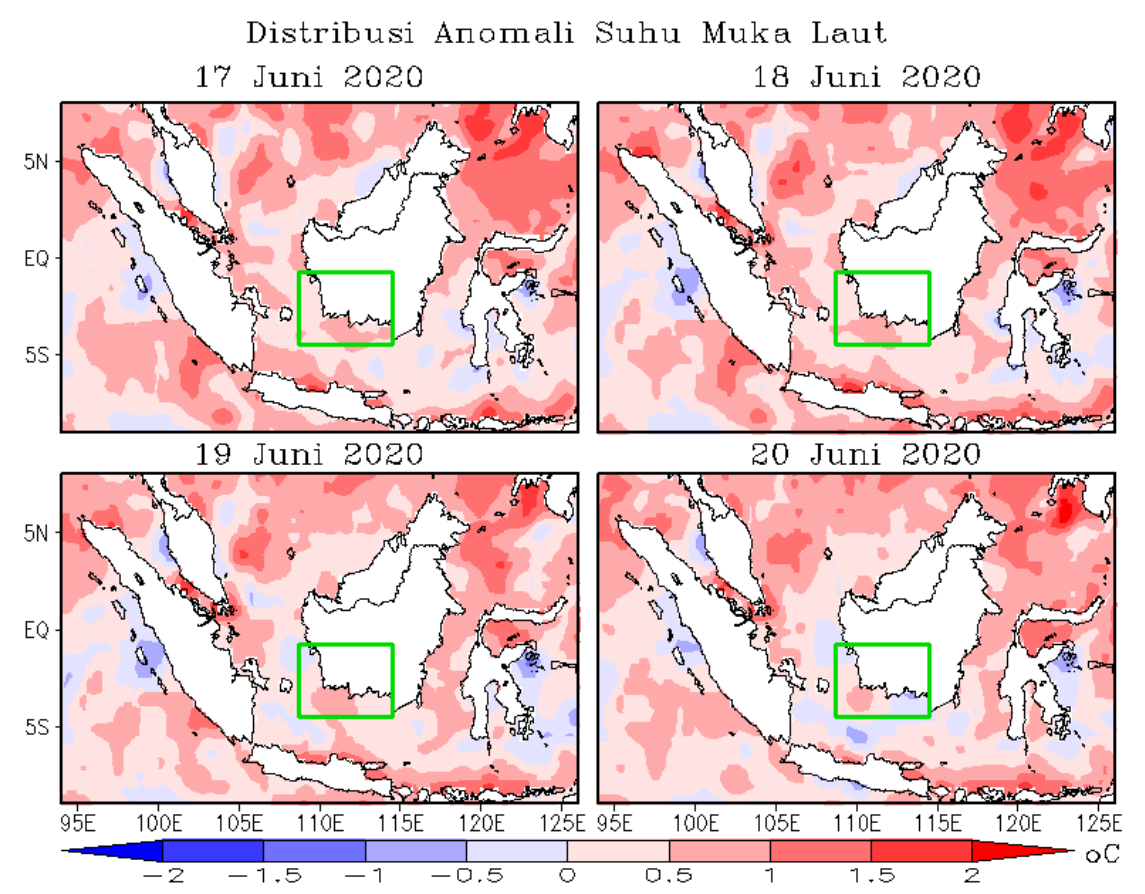

Gambar 2. Peta distribusi spasial anomali suhu permukaan laut 17 hingga 20 Juni 2020 


\section{Mean Sea Level Pressure (MSLP)}

Peta MSLP pada 20 Juni 2020 pukul 00 UTC ditunjukkan oleh Gambar 4. Tekanan di daratan Australia dan Asia secara umum memiliki nilai yang berbeda. Kecenderungan nilai tekanan lebih tinggi dimiliki oleh daratan Australia sedangkan daratan Asia memiliki tekanan dibawah $1000 \mathrm{mb}$. Perbedaan tekanan yang terjadi antara daratan Australia dan Asia dapat mempengaruhi pola sirkulasi atmosfer khususnya ketika melintasi Indonesia sehingga akan membawa perubahan cuaca di suatu wilayah. Tren MSLP akan berkaitan kuat dengan kecenderungan arah moisture transport (Nygård dkk., 2020).

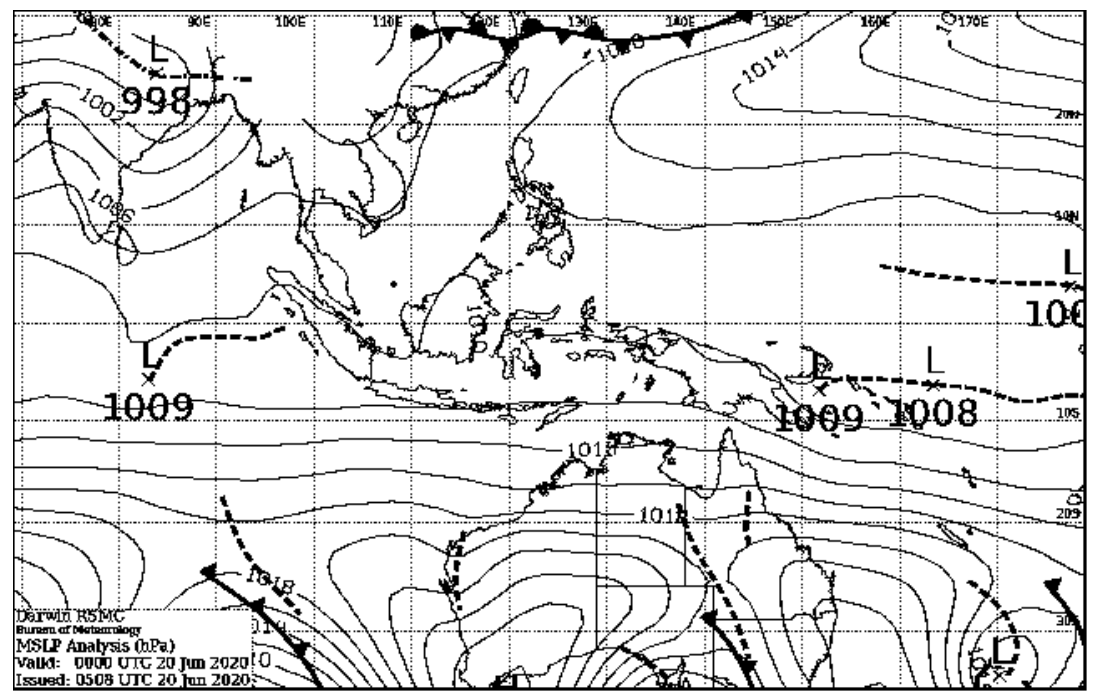

Gambar 3. Peta MSLP tanggal 20 Juni 2020 pukul 00.00 UTC

\section{Streamline Angin Gradien}

Peta angin gradien menunjukan adanya pola belokan angin (shearline) di sekitar Selat Karimata, seperti ditujukkan pada Gambar 4. Pola ini bertahan pada pukul 00.00 dan 12.00 UTC Belokan angin ini mengakibatkan adanya perlambatan kecepatan angin yang melalui suatu wilayah. Gangguan ini berimplikasi pada perlambatan aliran massa udara sehingga mengakibatkan penumpukan uap air di daerah sekitar belokan angin yang berpotensi sebagai tempat pertumbuhan awan konvektif (Kharisma \& Widomurti, 2018).

(a)

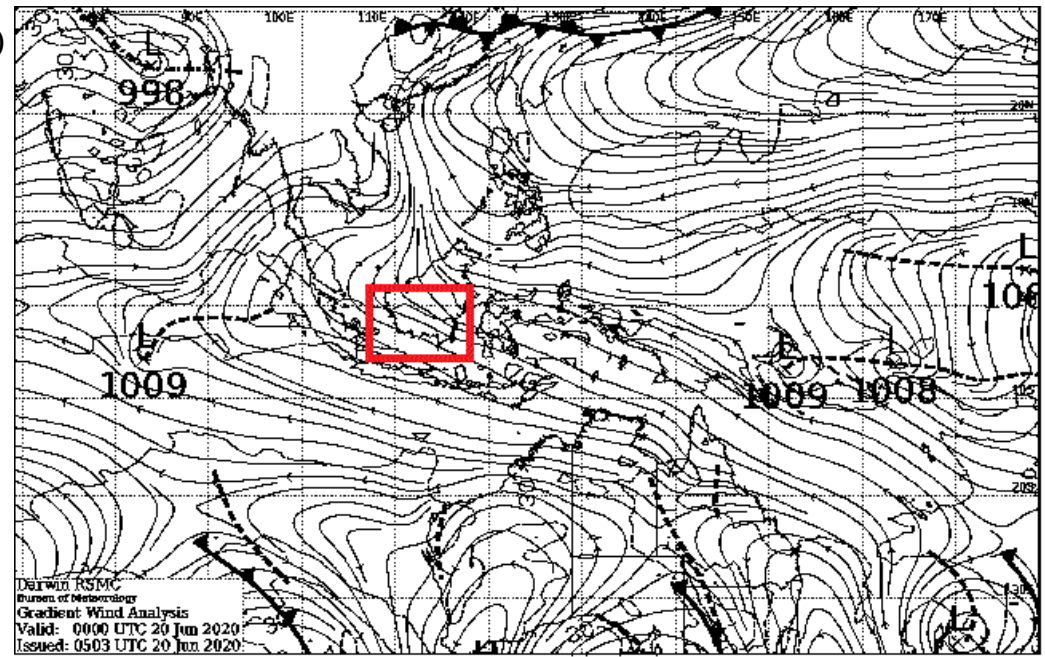


(b)

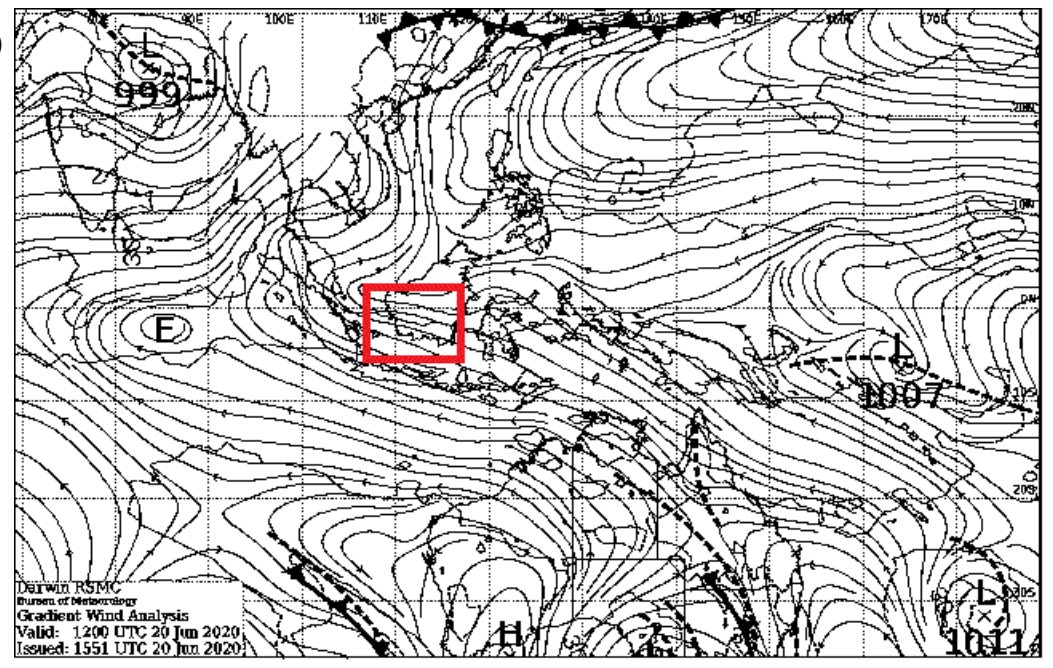

Gambar 4. Peta streamline angin gradien 20 Juni 2020 (a) 00.00 UTC dan (b) 12.00 UTC

\section{Moisture Transport}

Analisis vertikal yang telah dilakukan pada lapisan 1000 hingga $300 \mathrm{mb}$ menunjukan bahwa konsentrasi moisture transport lebih tinggi pada lapisan 500-300 mb dibandingkan lapisan lainnya seperti ditunjukkan pada Gambar 5. Peristiwa tersebut terjadi karena Benua Maritim menunjukan peningkatan kelembapan pada atmosfer lapisan menengah hingga atas melalui mekanisme low frequency upward dan penurunan kelembapan dilapisan bawah karena variabilitas frekuensi yang tinggi (Nasuno, 2019). Arah pergerakan secara horizontal dominan berasal dari timur-tenggara pada pukul 00.00 dan 06.00 UTC hingga mengalami perubahan arah menjadi timur laut-timur pada pukul 12.00 dan 18.00 UTC. Moisture transport dapat memiliki nilai dan arah yang berbeda pada setiap lapisan atmosfer (Xiaoxia dkk, 2010). Moisture transport di atmosfer merupakan proses yang sangat penting dalam terjadinya presipitasi. Hujan di wilayah penelitian terjadi pada rentang waktu 06.00-12.00 UTC sehingga dianalisis bahwa konsentrasi yang melalui lokasi penelitian cenderung lebih tinggi dibandingkan wilayah lainnya yaitu lebih dari $60 \mathrm{~kg} / \mathrm{ms}^{-1}$.

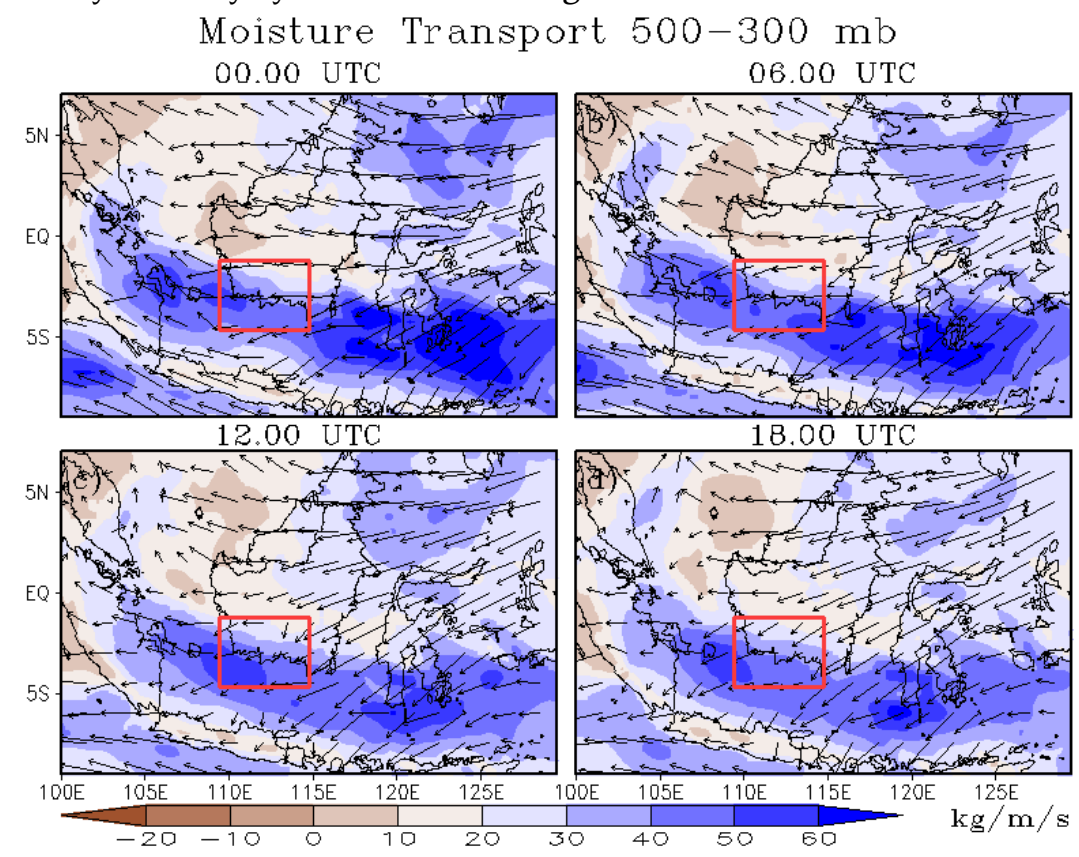

Gambar 5. Peta distribusi spasial moisture transport lapisan 500 - 300 mb 20 Juni 2020 
Analisis kondisi dinamika atmosfer yang dilakukan pada saat terjadi hujan lebat di Lamandau hingga menyebabkan banjir menunjukan bahwa faktor penyebab hujan lebat tersebut adalah belokan angin serta penguapan dari permukaan laut yang intensif di Teluk Kumai melalui analisis anomali. Belokan angin sebagai gangguan atmosfer ini menyebabkan adanya penumpukan massa udara. Pergerakan massa udara yang dapat ditinjau melalui moisture transport menunjukan bahwa pergerakan berasal dari timur-tenggara dengan konsentrasi tertinggi berada di lapisan menengah (lebih dari 60 $\left.\mathrm{kg} / \mathrm{ms}^{-1}\right)$.

\section{Analisis Awan Hujan}

Proses perkembangan awan dianalisis secara lebih rinci menggunakan produk CMAX dan MLVCUT dari radar cuaca. Analisis terbagi kedalam tiga tahap perkembangan awan yaitu, tahap pembentukan, matang dan disipasi. Tahap pembentukan awan ditunjukan oleh citra radar pada Gambar 6 (a) dan (b). Bibit awan terlihat pukul 09.00 UTC berada pada arah tenggara dari lokasi penelitian dan bergerak menuju barat laut. Struktur vertikal bibit awan ini ditinjau dari citra MLVCUT untuk membantu dalam analisis fase pertumbujan sistem awan (Hidayat dkk., 2019). Produk MLVCUT menunjukan bahwa jangkauan reflectivity maksimum yang dimiliki oleh awan ini mencapai $50 \mathrm{dBz}$ pada ketinggian sekitar $1 \mathrm{~km}$. Awan ini terlihat terus mengalami pertumbuhan vertikal ke atas hingga mencapai tahap matang.

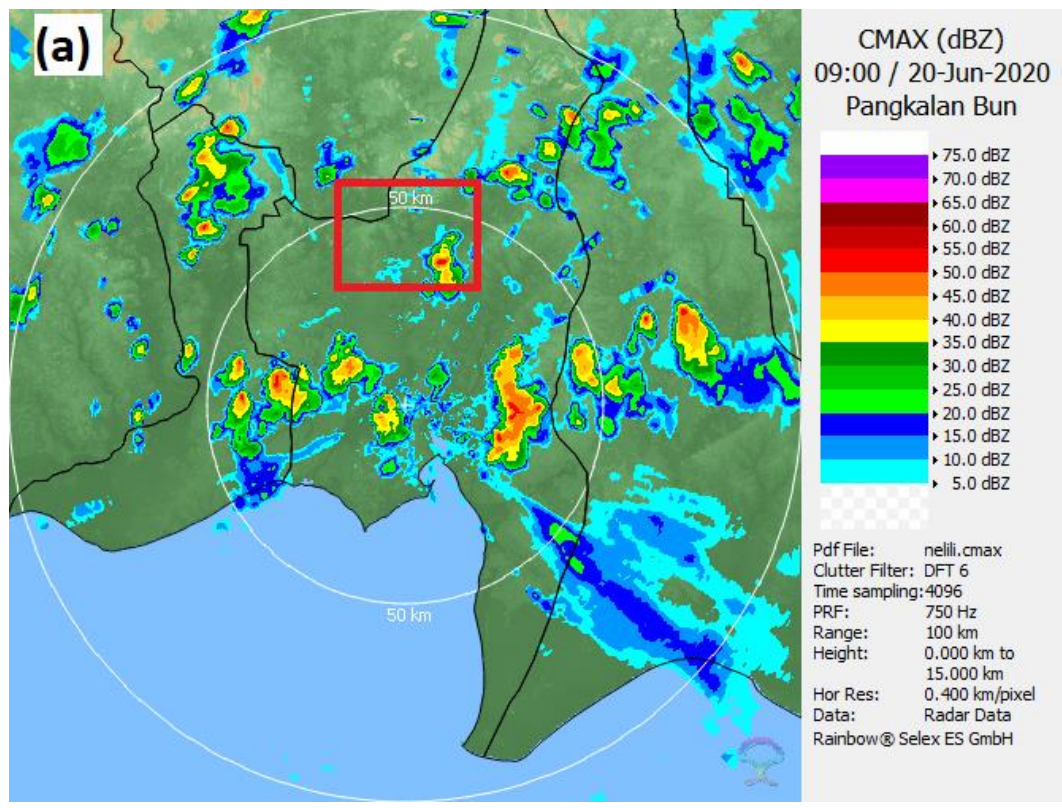




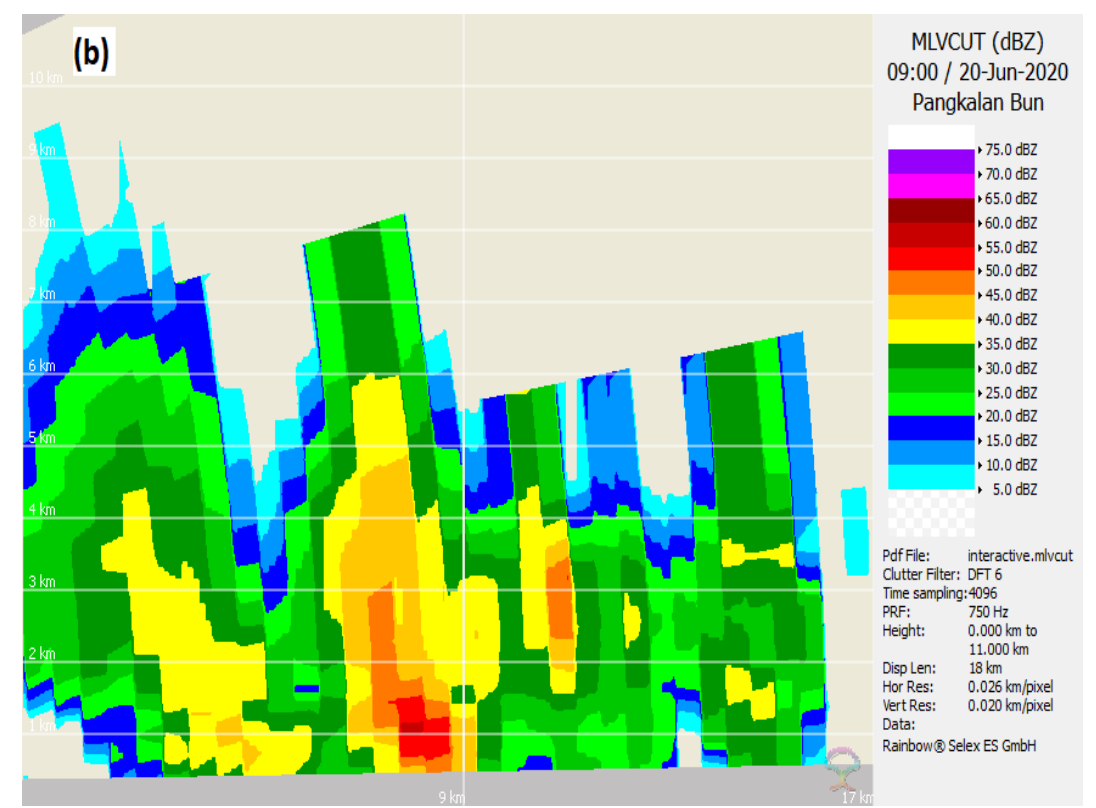

Gambar 6. Citra radar cuaca produk (a) CMAX dan (b) MLVCUT tanggal 20 Juni 2020 pukul 09.00 UTC pada tahap pertumbuhan.

Puncak dari tahap matang teridentifikasi pada pukul 10.00 UTC seperti ditunjukan pada Gambar 7. Tahap matang merupakan fase ketika bentuk awan mulai dalam kondisi stabil dan ukurannya konstan pada sistem perawanan (Anggoro \& Pramujo, 2017). Citra vertikal dari awan ini menunjukan adanya peningkatan reflectivity maksimum dibandingkan dengan tahap sebelumnya. Reflectivity maksimum sebesar $55-60 \mathrm{dBz}$ ini berada pada ketinggian $1.5 \mathrm{~km}$ dan $3 \mathrm{~km}$. Reflectivity tinggi yang terkonsentrasi di bagian bawah awan ini terjadi karena updraft tidak cukup mampu untuk menaikan tetes air (Hidayat dkk., 2019). Distribusi reflectivity dengan nilai yang lebih tinggi tersebar lebih merata pada seluruh bagian awan. Analisis sebaran awan secara spasial dilakukan melalui produk CMAX menunjukan perubahan distribusi horizontal serta perubahan lokasi dari awan yang menjadi objek penelitian. Gugusan awan terlihat semakin mendekati lokasi penelitian pada tahap matang. Merujuk pada Tabel 1 oleh Widomurti, awan yang meliputi wilayah penelitian dikategorikan sebagai awan konvektif yang memiliki potensi untuk menimbulkan hujan dengan intensitas sangat lebat. Kondisi presipitasi pada tahap ini akan dibahas lebih lanjut pada sub bab analisis curah hujan. 

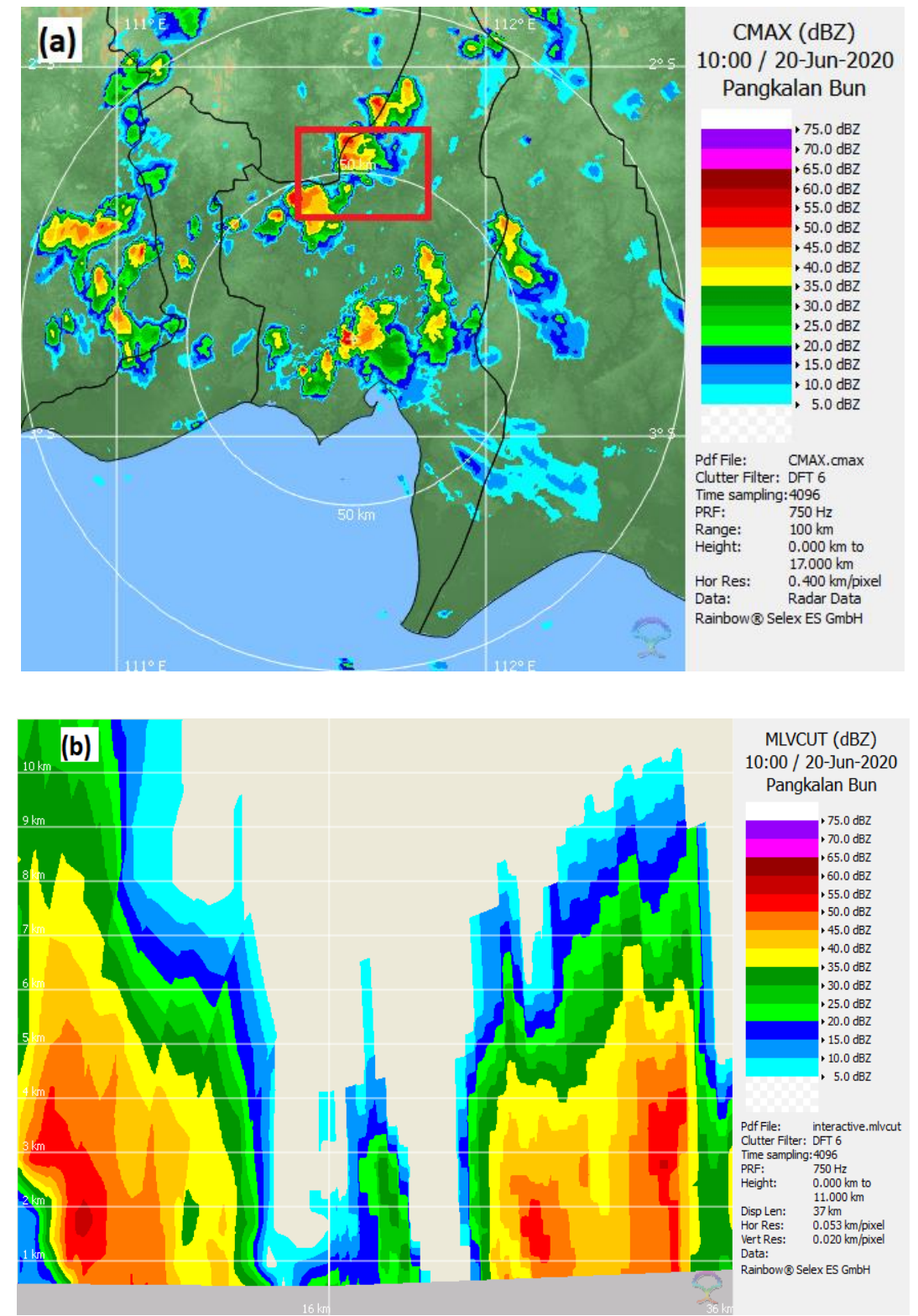

Gambar 8. Citra radar cuaca produk (a) CMAX dan (b) MLVCUT tanggal 20 Juni 2020 pukul 10.00 UTC pada tahap matang

Tahap disipasi merupakan fase dimana awan mengalami penurunan nilai reflectivity maksimum (Anggoro \& Pramujo, 2017). Struktur vertikal dari awan yang berada di lokasi penelitian mulai mengalami penurunan intensitas seperti yang ditunjukan oleh produk MLVCUT pada Gambar 9. Intensitas maksimum yang dimiliki oleh awan ini mencapai $40-45 \mathrm{dBz}$ dan terkonsentrasi pada bagian bawah awan. Wilayah statiform terbentuk melalui tinjauan spasial di wilayah penelitian. 

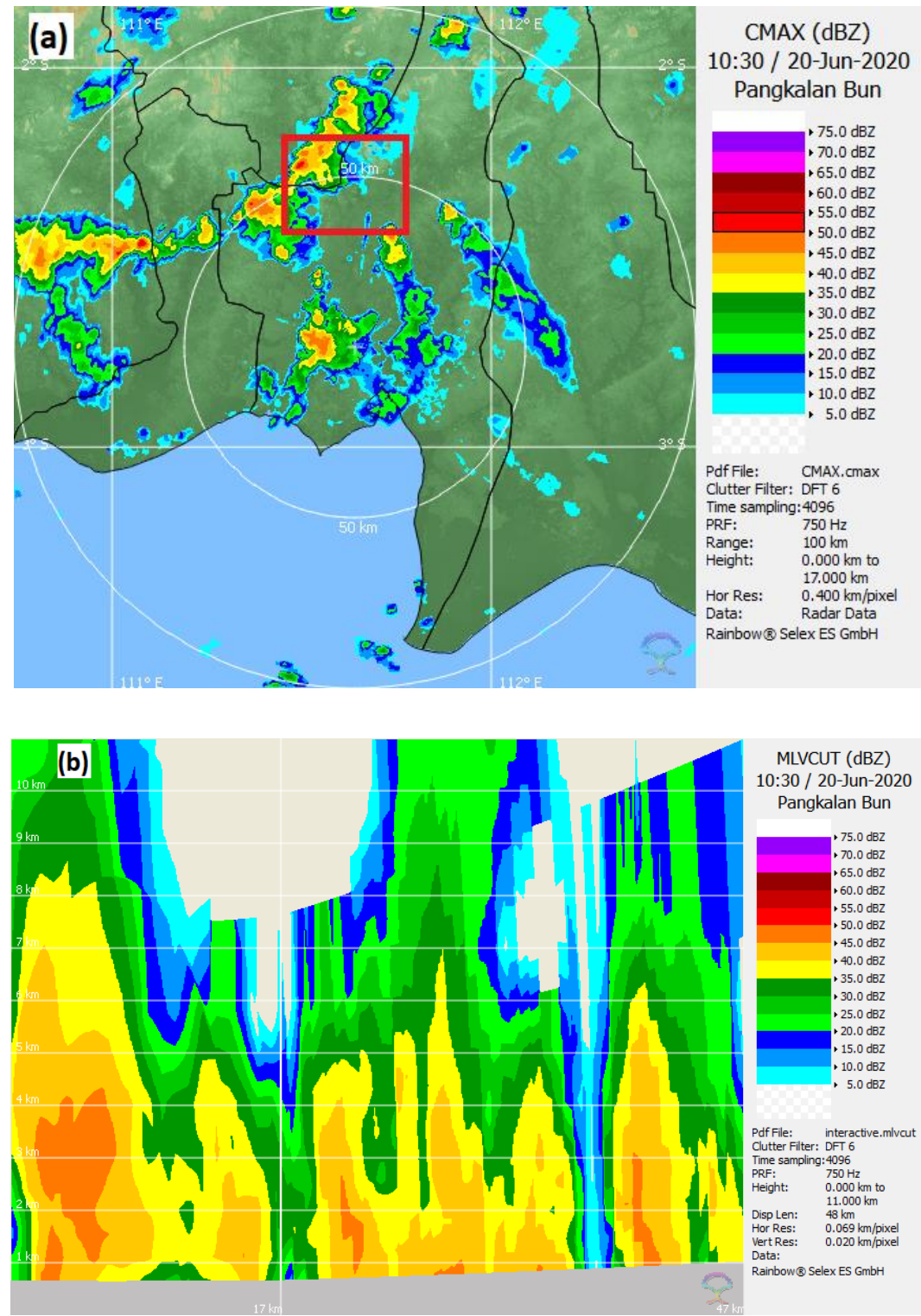

Gambar 9. Citra radar cuaca produk (a) CMAX dan (b) MLVCUT tanggal 20 Juni 2020 pukul 10.00 UTC pada tahap matang

\section{Analisis Curah Hujan}

Penelitian yang dilakukan oleh Hidayat dkk (2019) menunjukan bahwa produk SRI mampu memberikan nilai informasi intensitas curah hujan yang mendekati dengan nilai curah hujan milik Automatic Rain Gauge (ARG). Produk SRI membantu proses analisis presipitasi yang turun di lokasi penelitian secara spasial. Intensitas hujan terlihat cukup tinggi di wilayah penelitian dibandingkan dengan wilayah lainnya. Nilai intensitas maksimumnya dapat mencapai $50.1 \mathrm{~mm} / \mathrm{jam}$. Curah hujan yang terukur selama 24 jam di pos hujan Sematu Jaya menunjukan nilai $68.3 \mathrm{~mm}$.

Perubahan intensitas curah hujan terhadap waktu dianalisis lebih lanjut menggunakan produk RIH pada Gambar 10. Grafik histogram tersebut menunjukan bahwa terjadi hujan pukul 09.50 hingga 10.30 UTC pada pos hujan Sematu Jaya yang digunakan sebagai titik analisis. Puncak dari intensitas hujan terjadi pada pukul 10.00 UTC dimana fase puncak dari tahap matang terjadi dengan nilai 
mencapai $55.2 \mathrm{~mm} / \mathrm{jam}$. Intensitas hujan kemudian mengalami penurunan hingga sepenuhnya berhenti pada 10.30 UTC.
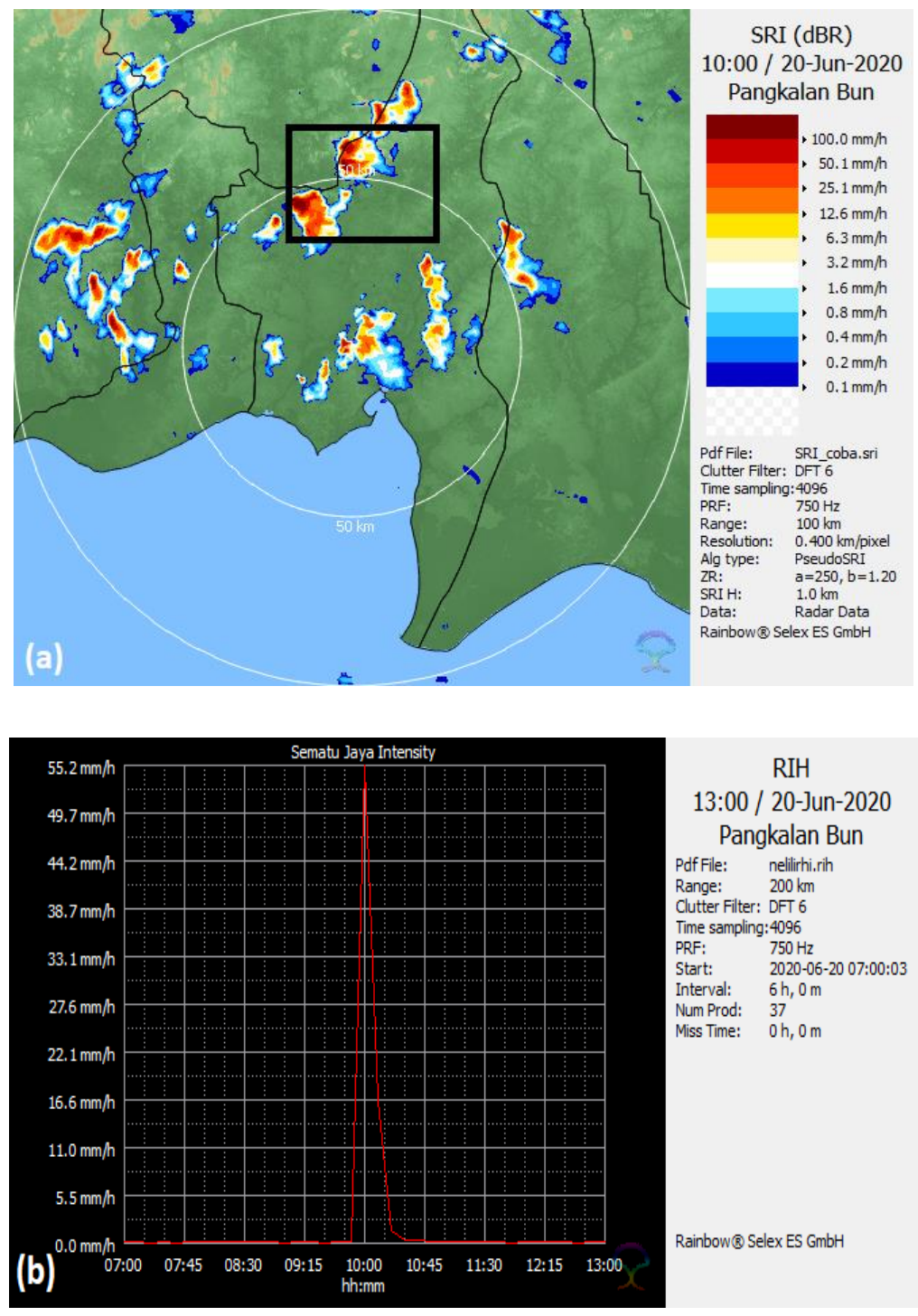

Gambar 10. Citra radar cuaca tanggal 20 Juni 2020 (a) produk SRI pukul 10.00 UTC dan (b) produk RIH pukul pukul 07.00 - 13.00 UTC

\section{SIMPULAN}

Kondisi dinamika atmosfer menunjukan bahwa faktor gangguan penyebab hujan lebat yaitu adanya pemanasan intensif pada perairan Laut Jawa bagian utara yang dapat mendukung pasokan uap air serta belokan angin. Belokan angin sebagai gangguan atmosfer ini menyebabkan adanya penumpukan massa udara. Pergerakan massa udara oleh moisture transport yang memiliki pergerakan dari timur - tenggara dengan konsentrasi tertinggi berada di lapisan menengah hingga atas (lebih dari $60 \mathrm{~kg} / \mathrm{ms}^{-1}$ ). Citra yang ditunjukan oleh reflectivity awan dimana awan yang terbentuk pada kasus ini adalah awan konvektif dengan nilai reflectivity maksimum sebesar 55-60 dBz pada ketinggian 1.5 hingga $3 \mathrm{~km}$. Jenis awan yang menyebabkan hujan di wilayah penelitian menurut klasifikasi VIP level adalah awan konvektif yang termasuk kedalam kategori sangat lebat. Distribusi hujan yang timbul tidak hanya terjadi di lokasi penelitian akan tetapi merata di wilayah sekitarnya dari analisis SRI. RIH menunjukan perubahan intensitas hujan secara lebih detail terhadap waktu sehingga diketahui bahwa 
terjadi peningkatan intensitas hujan secara signifikan dan mencapai puncaknya pada pukul 10.00 UTC dengan nilai $55.2 \mathrm{~mm} /$ jam di pos hujan Sematu Jaya.

\section{REFERENSI}

Adi, S. (2013). Karakterisasi Bencana Banjir Bandang di Indonesia. Jurnal Sains dan Teknologi Indonesia, $15,42-51$.

Anggoro, M. D., \& Pramujo B. (2017). Kajian waktu hidup dan pergerakan awan konvektif berbasis citra radar dan model ECMWF. Jurnal Meteorologi Klimatologi dan Geofisika, 4 No 3, 24-31.

Azka, M. A., Dzikiro, T. K., Simanjuntak, J. T., \& Winarso P. A. (2018). Kajian kondisi atmosfer terkait banjir di kabupaten Cilacap pada tanggal 7 Oktober 2017. Prosiding Seminar Nasional Fisika dan Aplikasinya, 173-183

Dewi, N. K. T. (2018). Estimasi curah hujan kuantitatif berbasis data radar cuaca di Pangkalan Bun, (Diploma's thesis). Sekolah Tinggi Meteorologi Klimatologi dan Geofisika, Indonesia

Gunawan, D., Endarwin, \& Pradana, R. P. (2013). Pemanfaatan data gelombang mikro pasif dan inframerah dalam pemisahan butiran awan konvektif dan stratiform. Jurnal Meteorologi dan Geofisika, 14 No. 1, 45-51.

Habib, A. H. Al, Pradana, Y. W., Pangestu, D., Winarso, P. A., \& Sujana J. (2019). Kajian pertumbuhan awan hujan pada saat banjir bandang berbasis citra satelit dan citra radar (Studi kasus: Padang, 2 November 2018). Jurnal Meteorologi Klimatologi dan Geofisika. 6 No. 2, 1-6.

Hidayat, A. M., Aofany, D., Arfianti, D. R., Nugraheni, I. R., \& Ali, A. (2019). Prediksi Intensitas Curah Hujan Menggunakan Produk Nowcasting Rtr Dibandingkan Dengan Produk Estimasi Curah Hujan Sri Pada Kejadian Banjir di Palembang Tanggal 12 - 13 November 2018. Jurnal Meteorologi Klimatologi Dan Geofisika, 6(1), 1-12.

Kharisma, S., \& Widomurti, L. (2018). Analisis hujan lebat dengan menggunakan data citra satelit di Kabupaten Banjarnegara. Jurnal Material Dan Energi Indonesia, 08(01), 29-35.

Kristianto, A., \& Putri, D. M. (2020). Kajian awal simulasi banjir di Bengawan Solo berbasis data GSMaP dan model cuaca numerik: (studi kasus banjir Bengawan Solo 05 - 07 Maret 2019). Jurnal Meteorologi Klimatologi dan Geofisika. 6(3), 39-47.

Mughozali, S. Al, Firdianto, P. U., \& Irawan, A. M. (2017). Analisis hujan lebat dan angin kencang di wilayah Banjarnegara study kasus Rabu, 8 November 2017. Unnes Physics Journal, 6(1), 6569.

Nasuno, T. (2019). Moisture Transport over the Western Maritime Continent during the 2015 and 2017 YMC Sumatra Campaigns in Global Cloud-System-Resolving Simulations. SOLA, 15. 99-106

Nuryanto, D. W., \& Anggraeni, R. (2017). Karakteristik anomali suhu muka laut pada Laut Jawa 1982 - 2014. Jurnal Meteorologi dan Geofisika, 18(3), 133-139.

Nygård, T., Naakka, T., \& Vihma, T. (2020). Horizontal Moisture Transport Dominates the Regional Moistening Patterns in the Arctic. Journal of Climate, 33(16), 6793-6807.

Paski, J. A. I., \& Permana D. S. (2018). Using the C-Band Doppler weather radar data to reconstruct extreme rainfall event on 11th march 2018 in Bangka island, Indonesia. MATEC Web Conference, 229

Prasetyo, B., Pusparini, N., Irawandi, \& Fitria, W. (2019). Aplikasi radar cuaca untuk identifikasi fluktuasi kondisi cuaca ekstrem (Studi kasus: banjir di kota Medan tanggal 5 Oktober 2018). Jurnal Sains \& Teknologi Modifikasi Cuaca, 20(1), 13-21.

Nababan, M., \& Tjasyono, B. (2016). Studi kejadian bencana banjir berdasarkan karakteristik awan dan hujan di wilayah Jakarta (Studi kasus 17 Januari 2014 ). Jurnal Meteorologi Klimatologi Dan Geofisika, 3(1), 15-23.

Xiaoxia, Z., Yihui, D., \& Panxing W. (2010). Moisture Transport in the Asian Summer Monsoon Region and Its Relationship with Summer Precipitation in China. Journal of Meteorological Research, 24(1): 31-42.

Widomurti, L. (2017). Penentuan rentang Video Integrator Processor (VIP) level curah hujan berdasarkan klasifikasi awan pada pengamatan radar cuaca (Diploma's thesis). Sekolah Tinggi Meteorologi Klimatologi dan Geofisika, Indonesia. 